\title{
PERBEDAAN MOTIVASI MENYELESAIKAN SKRIPSI ANTARA MAHASISWA YANG BEKERJA DENGAN MAHASISWA YANG TIDAK BEKERJA
}

\author{
Nidya Dudija \\ Institut Manajemen Telkom \\ Jalan Gegerkalong Hilir 47 Bandung \\ Nidyanudija@gmail.com
}

\begin{abstract}
This study aims to examine whether there is difference in motivation to complete a thesis between employed students with unemployed students. Motivation to complete a thesis scale was used to get the data. T-test was used to analysis data. The result of t-test confirmed that there is a significant difference in motivation to complete thesis between employed student with unemployed student $(t=4.085)$ with $\mathrm{p}=0.000<0.05)$. Employed student had higher motivation than unemployed student in completion their thesis. This result will be discussed further.
\end{abstract}

Keywords: Completion the Thesis, Motivation, Student.

\begin{abstract}
Abstrak
Penelitian ini bertujuan untuk mengetahui apakah ada perbedaan motivasi menyelesaikan skripsi antara mahasiswa yang bekerja dengan mahasiswa yang tidak bekerja. Data dikumpulkan dengan skala motivasi menyelesaikan skripsi. Data dianalisis menggunakan teknik Uji-t. Hasil analisis uji- $t$ diperoleh nilai $t=4,085$ dengan $p=0,000$, karena signifikansi uji $\mathrm{t}=0,000<\mathrm{p} 0,01$ artinya sangat signifikan. Dapat disimpulkan bahwa terdapat perbedaan motivasi menyelesaikan skripsi yang sangat signifikan antara mahasiswa yang bekerja dan mahasiswa yang tidak bekerja. Mahasiswa bekerja memiliki motivasi menyelesaikan skripsi lebih tinggi sedangkan mahasiswa yang tidak bekerja memiliki motivasi menyelesaikan skripsi lebih rendah.
\end{abstract}

Kata kunci: Mahasiswa, Motivasi, Penyelesaian Skripsi. 


\section{Pendahuluan}

Fenomena mahasiswa kerja sambilan kiranya bukan hal baru. Banyak dari mahasiswa tersebut mencari tambahan penghasilan untuk mencukupi kebutuhan kuliah yang semakin menggunung. Kuliah sambil bekerja tidak lagi menjadi sesuatu hal yang langka dan hanya dilakukan mahasiswa yang lemah dalam ekonomi, karena kenyataannya biaya hidup sehari-hari seringkali tidak sebanding dengan uang saku yang diberikan oleh orang tua. Berdasarkan Undang-Undang Ketenagakerjaan pengertian dari tenaga kerja adalah setiap orang yang mampu melakukan pekerjaan guna menghasilkan barang dan/atau jasa baik untuk memenuhi kebutuhan sendiri maupun untuk masyarakat. Lebih lanjut dijelaskan pada Bab III Pasal 5, setiap tenaga kerja memiliki kesempatan yang sama tanpa diskriminasi untuk memperoleh pekerjaan. Dalam hal ini mahasiswa adalah termasuk salah satu individu yang berhak untuk bekerja dan memperoleh penghasilan yang layak.

Menurut Putri (2006) sekarang ini, para mahasiswa yang berasal dari kalangan berada (mampu secara ekonomi) tidak sedikit yang beraktivitas untuk menambah uang saku atau pengalaman mereka. Mahasiswa di dunia kampus, sudah tampak lebih dewasa dan mampu mengolah pikir untuk mencari pekerjaan. Mereka seakan acuh tak acuh dengan jerih payah orang tua yang telah mengucurkan keringat membiasakan mengirim anak dengan uang hasil dari kerja. Hal ini pula yang terjadi pada mahasiswa khususnya mahasiswa Teknik informatika UAD. Ada sebagian diantara mereka yang tidak perduli dengan besarnya tanggung jawab sebagai seorang mahasiswa yang sedang menyelesaikan skripsinya. Namun, mereka tetap memiliki keinginan untuk bekerja baik yang berhubungan secara teknis ataupun tidak.

Mahasiswa yang bekerja, bila pekerjaan yang diambilnya sesuai dengan jurusan yang ditempuh hal itu akan sangat membantu dalam hal penyusunan skripsi. Mahasiswa tersebut akan lebih mudah menerapkan ilmu yang didapat dari pengalaman kerjanya kedalam bentuk karya tulis. Motivasi untuk menyelesaikan skripsi bagi mahasiswa yang sambil bekerja ada juga yang justru semakin meningkat karena keinginan mereka untuk cepat menyelesaikan studi dipacu oleh pekerjaan mereka.

Bekerja merupakan perwujudan dari aktualisasi diri. Puncak dari kebutuhan manusia menurut Maslow adalah beraktualisasi diri. Perwujudan aktualisasi diri akan nampak dari hasil usaha yang dikerjakan secara penuh dan sungguh-sungguh. Dengan berusaha melatih diri secara terus menerus secara maksimal akan menempa pribadi lebih tangguh menghadapi pasang surut kehidupan. Pendidikan di bangku kuliah akan mendorong usaha mahasiswa untuk ulet dan mempunyai pengalaman secara dinamis 
tentang aplikasi teori-teori yang didapat dari kampus.

Bekerja mencari rezeki untuk memberi nafkah keluarga digolongkan beramal di jalan Allah (Fi Sabilillah). Sebagaimana Sabda Nabi SAW, "Jika ada seseorang yang keluar dari rumah untuk bekerja guna mengusahakan kehidupan anaknya yang masih kecil, maka ia telah berusaha di jalan Allah. Jikalau ia bekerja untuk dirinya sendiri agar tidak sampai meminta-minta pada orang lain, itu pun di jalan Allah. Tetapi jika ia bekerja untuk berpamer atau bermegah-megahan, maka itulah 'di jalan setan' atau karena mengikuti jalan setan" (HR. Thabrani). Rasulullah SAW pernah ditanya, "Pekerjaan apakah yang paling baik?" Beliau menjawab, "Pekerjaan terbaik adalah usahanya seseorang dengan tangannya sendiri dan semua perjualbelian yang dianggap baik" (HR. Ahmad, Baihaqi, dan lain-lain).

Beberapa hal yang bisa dikatakan menjadi "bumerang" bagi mahasiswa yang sambil bekerja adalah hasil dan tujuan studi yang sedang mereka jalani akan terhambat jika mereka tidak bisa mengatur waktu dengan manajemen yang baik, bahkan dikhawatirkan mahasiswa yang sambil bekerja tersebut sudah tidak lagi memperdulikan studi mereka. Motivasi untuk menyelesaikan studi bagi mahasiswa yang sambil bekerja yang sudah sampai kepada tahap akhir studi untuk menyelesaikan skripsinya bisa saja juga mengalami penurunan karena mereka merasa pekerjaan yang merekajalani saat ini sudah cukup untuk bekal mereka hidup.

Menurut Sya'ban (2006) bagi mahasiswa yang tidak bekerja motivasi untuk menyelesaikan skripsi itu biasanya di latar belakangi oleh tuntutan yang ada baik dari dalam diri mereka sendiri ataupun dari orang lain. Menyelesaikan skripsi bagi mahasiswa yang tidak bekerja merupakan pilihan tunggal. Motivasi yang mereka dapatkan terkadang hanya karena proses untuk menyelesaikan studi yang harus mereka lalui.

Keadaan ekonomi keluarga bagi mahasiswa yang bekerja untuk menyelesaikan skripsi merupakan suatu motivasi tersendiri. Keadaan yang dimaksud adalah keadaan ekonomi yang kurang mampu sehingga mempengaruhi mahasiswa tersebut untuk bekerja mencari biaya hidup sendiri. sehingga lebih termotivasi untuk membantu keluarga. Namun bagi mahasiswa yang tidak bekerja yang keadaan ekonominya juga kurang mampu namun tidak bekerja menyelesaikan skripsi merupakan suatu motivasi tersendiri untuk mengurangi beban hidup yang ditanggung oleh orang tua, karena di Indonesia pada umumnya orang mencari kerja harus menyelesaikan suatu tahapan studi. Sehingga bagi mahasiswa tersebut menyelesaikan skripsi merupakan suatu tahapan untuk mendapatkan modal bekerja. Sedangkan bagi mahasiswa yang berkecukupan baik yang bekerja ataupun yang tidak bekerja menyelesaikan skripsi 
merupakan suatu jalur untuk menyelesaikan studinya yang kemudian langkah selanjutnya adalah pilihan dari individu masing-masing.

Menurut data dari Kompas Cyber Media (www.Kompas.com), sebenarnya dari mahasiswa bekerja ada beberapa manfaat penting dari fenomena mahasiswa nyambi tersebut. Pertama, mahasiswa mampu berbuat praktis. Artinya, mahasiswa tidak lagi terjebak pada wacana-wacana teoretis saja, tetapi juga mampu mengaplikasikan apa yang telah dia dapatkan di kampus ke dalam pekerjaannya. Sebab, dalam dunia kerja mahasiswa dihadapkan pada persoalan-persoalan riil yang harus mampu mereka pecahkan secara tepat dan cepat.

Kedua, mahasiswa mampu bersikap lebih independen dan konsisten. Kenyataan sering membuktikan, hanya karena diberi handphone, mendapat uang saku tambahan, dan tercukupinya beberapa keperluan material lainnya, mahasiswa lantas mau bertindak yang bertentangan dengan kepentingan yang lebih besar.

Ketiga, mahasiswa mampu berpikir lebih kreatif. Pengalaman yang didapat mahasiswa pada saat bekerja di luar jam kuliah akan berpengaruh terhadap jiwa kewirausahaannya.

Keempat, mahasiswa memiliki jiwa profesionalisme. Mahasiswa telah terbiasa dalam lingkungan yang dinamis dan kompetitif, sehingga peluang untuk melakukan praktik-praktik manipulatif tidak diberi ruang yang cukup. Kemudian yang muncul adalah benih-benih profesionalisme dan lambat laun akan menjadi ciri khas sang mahasiswa tersebut. Pada saatnya nanti, sang mahasiswa tersebut kelak mampu membawa pengalamannya ke dunia riil.

Dengan demikian, tidak ada lagi cibiran bagi mahasiswa yang nyambi karena ternyata justru memunculkan pengalaman-pengalaman tambahan yang dapat bermanfaat bagi dirinya dan juga lingkungan sekitarnya.

Meskipun begitu, dalam hal ini waktu yang tersedia untuk meyelesaikan skripsi pada mahasiswa bekerja menjadi sangat terbatas karena waktunya lebih banyak digunakan untuk bekerja. Melalui hasil observasi maupun interview langsung oleh penulis dengan subyek mahasiswa bekerja dan tidak bekerja maka diperoleh, mahasiswa yang bekerja hanya memiliki waktu kurang lebih 3 jam untuk menyelesaikan skripsi per harinya. Waktu tersebut telah dikurangi dari waktu bekerjanya sebanyak 5-8 jam/hari, istirahat 8 jam/hari ke kampus atau kegiatan lainnnya 5 jam/hari. Sedangkan mahasiswa yang tidak bekerja memiliki waktu luang yang lebih banyak dari pada mahasiswa yang bekerja. Diperkirakan mahasiswa yang tidak bekerja memiliki waktu luang kurang lebih $10 \mathrm{jam} / \mathrm{harinya}$. Dimana waktu ini telah dikurangi dengan waktu untuk istirahat dan kegiatan lainnya. 
Hasil pengamatan di atas dapat di lihat bahwa perbedaan selisih waktu antara mahasiswa yang bekerja dan mahasiswa yang tidak bekerja kurang lebih sebesar 7 jam. Adanya perbedaan waktu antara mahasiswa bekerja dan mahasiswa tidak bekerja tentunya akan menimbulkan perbedaan motivasi dalam menyelesaikan skripsi.

Menurut kamus lengkap psikologi motivasi adalah suatu variabel penyelenggara (yang ikut campur) yang digunakan untuk membuka faktor faktor tertentu di dalam organisme yang membuktikan, mengelola, mempertahankan dan menyalurkan tingkah lakunya menuju suatu sasaran (Chaplin, 2001). Menurut Sya'ban (2006) skripsi dapat dikatakan sebagai sebuah puncak kulminasi prestasi, pembuktian keilmuan, bahkan merupakan sarana sumbangsih seorang mahasiswa bagi masyarakat. Proses yang akan ditempuh dalam mengerjakan skripsi cukup panjang mulai dari menentukan judul/tema, membuat proposal penelitian, seminar sampai dengan melakukan penelitian secara mandiri. Seorang mahasiswa harus memiliki motivasi yang tinggi dalam dirinya untuk menyelesaikan skripsi. Menurut Hadi (2001), dalam skripsi mahasiswa dituntut mengerahkan kemahiran berpikir, bersikap dan bertindak dalam usaha menggali dan mengembangkan pengetahuan yang baru untuk disumbangkan dalam bidang keahliannya. Selain itu dituntut untuk menerapkan kaidah dan etika ilmiah yang berlaku di lingkungan masyarakat ilmiah. Dalam mengerjakan sebuah tugas (skripsi) mahasiswa tidak bekerja sendiri mahasiswa juga dibantu oleh dosen pembimbing skripsi agar dalam mengerjakan skripsi tersebut mahasiswa tidak keluar dari kaidah atau jalur yang akan diteliti.

Berdasarkan pengertian pengertian diatas, dapat ditarik kesimpulan bahwa motivasi menyelesaikan skripsi adalah suatu usaha atau tenaga pendorong yang mempengaruhi tingkah laku seseorang agar tergerak hatinya untuk menyelesaikan suatu karya tulis ilmiah hasil penelitian mandiri yang disusun berdasarkan hasil penelitian di perpustakaan, di lapangan atau di laboratorium untuk memenuhi sebagian persyaratan memperoleh derajat kesarjanaan S-1.

Suryabrata (1995) berpendapat bahwa ada enam cara yang dapat dilakukan untuk meningkatkan motivasi,yaitu:

a. Menumbuhkan motif motif sebanyak mungkin.

b. Hindarkan sugesti yang bersifat negative menggunakan sugesti positif.

c. Mengadakan persaingan yang sehat baik secara individu maupun secara kelompok.

d. Dengan Self Competition.

e. Tetapkan tujuan sementara atau tujuan perantara sehingga sasaran yang akan dicapai menjadi jelas. 


\section{f. Mengadakan diskusi.}

Keenam cara meningkatkan motivasi ini efektif untuk dilaksanakan dan dipakai sesuai dengan kondisi dan kebutuhan individu.

Menurut Bass (1961), status adalah harga/nilai dari posisi yang diduduki seseorang dalam suatu kelompok. Sependapat dengan Bass, Krench (1962) mengatakan status adalah tingkatan di suatu posisi/kedudukan individu dalam suatu kelompok atau komunitas. Status diartikan sebagai tempat atau posisi seseorang dalam suatu kelompok sosial sehubungan dengan orang-orang lainnya dalam kelompok tersebut/tempat suatu kelompok sehubungan dengan kelompok lainnya di dalam kelompok yang lebih besar lagi.

Definisi kerja menurut Blum (1974) adalah suatu bentuk kegiatan atau aktivitas yang dilakukan oleh individu karena adanya dukungan dari individu untuk melakukannya, dengan bekerja seseorang berharap untuk dapat mencukupi kebutuhan kebutuhan hidupnya baik material maupun kebutuhan sosial psikologisnya.

Pengertian status kerja berdasarkan pendapat yang dikemukakan para ahli diatas adalah keadaan atau kedudukan orang atau badan yang diperoleh dari kegiatan secara langsung ataupun tidak langsung guna mendapatkan penghasilan dalam bentuk uang atau barang.

Mahasiswa adalah individu yang menuntut ilmu pada jenjang perguruan tinggi dan berstatus aktif. Menurut Jacinta (2002) yang mendasari seorang mahasiswa untuk bekerja diantaranya adalah:

\section{a. Kebutuhan Finansial}

Kebutuhan finansial berupa kebutuhan yang berhubungan dengan faktor ekonomi. Berupa upah, gaji dan penghasilan yang di dapat dari bekerja.

b. Kebutuhan Sosial Relasional

Kebutuhan sosial-relasional berupa kebutuhan untuk bergaul dengan banyak orang, dapat bertukar pikiran.

c. Kebutuhan Aktualisasi Diri

Abraham Maslow mengembangkan teori hirarki kebutuhan yang salah satunya mengungkapkan bahwa manusia membutuhkan kebutuhan akan aktualisasi diri, menemukan makna hidupnya melalui aktivitas yang dijalani. Bekerja adalah salah satu sarana atau jalan yang dapat dipergunakan oleh manusia dalam menemukan makna hidupnya. Melalui berkarya, berkreasi, mencipta, mengekspresikan diri, mengembangkan diri dengan orang lain, membagikan ilmu dan pengalaman, menemukan sesuatu serta mendapatkan penghargaan, penerimaan prestasi. Kebutuhan akan aktualisasi diri melalui profesi 
ataupun karir, merupakan salah satu pilihan yang banyak diambil oleh mahasiswa, terutama dengan makin terbukanya lapangan pekerjaan yang tidak membutuhkan tanda kelulusan perguruan tinggi.

Dapat ditarik kesimpulan bahwa pengertian dari mahasiswa bekerja adalah individu yang menuntut ilmu pada jenjang perguruan tinggi dan berstatus aktif, yang juga menjalankan usaha atau sedang berusaha mengerjakan suatu tugas yang diakhiri buah karya yang dapat dinikmati oleh orang yang bersangkutan.

Mahasiswa tidak bekerja adalah mahasiswa yang benar benar menuntut ilmu pada jenjang peguruan tinggi tanpa melakukan kegiatan apapun yang berhubungan dengan pekerjaan yang bersifat komersil.

Dapat disimpulkan bahwa bekerja atau tidak bekerja bagi mahasiswa adalah suatu pilihan. Keduanya sama-sama memiliki pengaruh negatif dan positif dalam diri seorang mahasiswa yang sedang berstatus aktif sebagai peserta didik dalam jenjang perguruan tinggi. Menunjukkan eksistensi diri atau mengaktualisasikan diri bagi seorang mahasiswa selain dengan bekerja dapat juga dilakukan dengan cara berkarya, berprestasi, berkreasi serta hal lainnya yang membawa dampak positif dalam pengembangan potensi dalam diri mahasiswa itu sendiri.

Hipotesis dalam penelitian ini adalah ada perbedaaan motivasi menyelesaikan skripsi antara mahasiswa yang bekerja dengan mahasiswa yang tidak bekerja. Mahasiswa yang bekerja mempunyai motivasi menyelesaikan skripsi lebih tinggi sedangkan mahasiswa yang tidak bekerja memiliki motivasi menyelesaikan skripsi lebih rendah.

\section{Metode Penelitian}

Variabel ini diukur dengan skala motivasi terdiri dari aitem-aitem yang favorabel dan unfavorabel dengan lima pilihan jawaban yaitu Sesuai (S), Sangat Sesuai (SS), Netral (N), Tidak Sesuai (TS), Sangat Tidak Sesuai (STS). Skor yang digunakan berkisar satu sampai dengan lima. Tinggi rendahnya skor yang dimiliki subyek menentukan kedudukan motivasi subyek dalam menyelesaikan skripsi. Semakin tinggi skor subyek maka semakin tinggi motivasi subyek dalam menyelesaikan skripsi, sebaliknya semakin rendah skor subyek maka semakin rendah motivasi subyek dalam menyelesaikan skripsi.

Penelitian ini digunakan teknik purposive sampling, yaitu peneliti menemukan/ mencari subyek yang memiliki ciri-ciri sesuai dengan populasi penelitian untuk dijadikan responden (Hadi, 2001). sampel pada penelitian ini sejumlah 35 orang mahasiswa 
yang bekerja dan 50 orang mahasiswa yang tidak bekerja. Jadi sejumlah 85 orang mahasiswa akan dijadikan sampel untuk penelitian ini.

Skala motivasi dibuat berdasarkan ciri-ciri individu yang memiliki motivasi tinggi menurut Brophy (1990). Butir-butir pernyatan terdiri dari 72 aitem, yang terdiri dari 36 pernyataan favorabel dan 36 pernyataan unfavorabel.

Analisis data yang digunakan dalam penelitian ini adalah dengan menggunakan analisis satu jalur karena untuk mengetahui perbedaan motivasi menyelesaikan skripsi antara mahasiswa yang bekerja dengan mahasiswa yang tidak bekerja. Model analisis statistik yang digunakan untuk menguji hipotesis tersebut adalah independent sample t-test yang merupakan suatu teknik statistik yang berfungsi untuk menguji signifikansi perbedaan rerata antara pasangan kelompok atau perbedaan rerata pasangan amatan ulang. Proses pengolahan data dalam penelitian ini dilakukan dengan bantuan program komputer Statistical Package for Social Science (SPSS) 11.5 for Windows.

\section{Hasil dan Pembahasan}

Skor subyek penelitian sebanyak 85 orang ditabulasikan untuk mempermudah proses analisis. Berdasarkan hasil analisis data statistik deskriptif diperoleh skor empirik dan skor hipotetik secara rinci dapat dilihat pada tabel 1 di bawah ini.

Tabel 1. Deskripsi Data Penelitian

\begin{tabular}{lccccccccc}
\hline Variabel & $\sum$ & \multicolumn{4}{c}{ Skor Empirik } & \multicolumn{4}{c}{ Skor Hipotetik } \\
\cline { 3 - 10 } & Aitem & Min & Maks & M & SD & Min & Maks & $\mu$ & $\sigma$ \\
\hline Bekerja & 51 & 162 & 215 & 200,08 & 12,89 & 51 & 255 & 153 & 34 \\
\hline $\begin{array}{l}\text { Tidak } \\
\text { Bekerja }\end{array}$ & 51 & 149 & 219 & 187,60 & 14,50 & 51 & 255 & 153 & 34 \\
\hline
\end{tabular}

Deskripsi data penelitian tersebut dapat dimanfaatkan untuk melakukan kategorisasi pada masing-masing variabel penelitian, yaitu dengan menetapkan kriteria kategori yang didasari oleh asumsi bahwa skor populasi subjek terdistribusi secara normal sehingga dapat dibuat skor teoritis yang terdistribusi menurut model normal (Azwar, 2000).

Kategorisasi yang akan digunakan adalah kategorisasi jenjang berdasarkan distribusi normal. Norma kategorisasi sebagai berikut:

$$
\begin{array}{ll}
\mathrm{x}<\mu \quad 1 \sigma & =\text { Rendah } \\
\mu \quad 1 \sigma \leq \mathrm{x}<\mu+1 \sigma & =\text { Sedang } \\
\mu+1 \sigma \leq \mathrm{x} & =\text { Tinggi }
\end{array}
$$


Kategori skor motivasi menyelesaikan skripsi pada mahasiswa yang bekerja dan mahasiswa yang tidak bekerja berdasarkan skor hipotetik disajikan pada tabel 2 berikut.

Tabel 2. Distribusi frekuensi skor hipotetik

\begin{tabular}{cccccc}
\hline$\%$ & Bekerja & Interval & kategori & Tidak Bekerja & $\%$ \\
\hline 0 & 0 & $X<119$ & Rendah & 0 & 0 \\
\hline 11,4 & 4 & $119 \leq X<187$ & Sedang & 22 & 44,0 \\
\hline 88,6 & 31 & $187 \leq X$ & Tinggi & 28 & 56,0 \\
\hline 100 & 35 & \multicolumn{2}{c}{ Jumlah } & 50 & 100 \\
\hline
\end{tabular}

Kategorisasi dari masing-masing variabel di atas, dapat juga diilustrasikan sebagai berikut:

Kriteria skor skala motivasi menyelesaikan skripsi

\begin{tabular}{ccc}
119 & 187 \\
\hline rendah & sedang & tinggi
\end{tabular}

Berdasarkan tabel diatas diperoleh kesimpulan bahwa distribusi frekuensi skor hipotetik motivasi menyelesaikan skripsi terlihat bahwa skor hipotetik motivasi menyelesaikan skripsi pada mahasiswa yang bekerja dan mahasiswa yang tidak bekerja berada pada kategori tinggi, pada mahasiswa bekerja sebesar $88,6 \%$ dan pada mahasiswa tidak bekerja $56 \%$.

Uji normalitas motivasi menyelesaikan skripsi dengan menggunakan analisis one-sample Kolmogorov-Smirnov Test. Hasil analisis tersebut diperoleh hasil onesample Kolmogorov-Smirnov Test sebesar 0,984 dengan probabilitas $(\mathrm{p})=0,288$, karena memiliki taraf probabilitas lebih dari 0,05 maka dapat disimpulkan bahwa variabel motivasi menyelesiakan skripsi mempunyai skor yang terdistribusi secara normal.

Tujuan dilakukan uji homogenitas adalah apakah kedua variabel tersebut memiliki skor variansi yang sama. Adapun teknik yang digunakan dalam uji homogenitas ini adalah Levene test. Pengujian signifikansi hasil perhitungan pada penelitian ini digunakan taraf signifikansi $5 \%$. Interpretasi hasil uji homogenitas adalah jika signifikansi Levene test lebih dari signifikansi 0,05 maka kedua variabel mempunyai skor yang variansi sama. Hasil analisis diperoleh nilai statistik Levene 
test sebesar 0,645 dengan $\mathrm{p}=0,424$, karena tingkat probabilitas statistik Levene test $\mathrm{p}=0,424>0,05$ maka dapat disimpulkan bahwa antara mahasiswa yang bekerja dan mahasiswa tidak bekerja memiliki varians skor yang sama.

Pengujian hipotesis pada penelitian ini digunakan analisis statistik uji t, analisis ini dilakukan untuk mengetahui apakah ada perbedaan motivasi menyelesaikan skripsi antara mahasiswa yang bekerja dengan mahasiswa yang tidak bekerja. Hasil analisis uji-t diperoleh nilai $\mathrm{t}=4,085$ dengan $\mathrm{p}=0,000$, karena signifikansi uji $\mathrm{t}=0,000<\mathrm{p}$ 0,01 artinya sangat signifikan. Dapat disimpulkan bahwa ada perbedaan motivasi menyelesaikan skripsi antara mahasiswa yang bekerja dengan mahasiswa yang tidak bekerja pada mahasiswa jurusan Teknik Informatika UAD, maka hipotesis dalam penelitian ini diterima.

Hasil data frekuensi skor hipotetik motivasi menyelesaikan skripsi pada mahasiswa bekerja terbagi dalam tiga kategori, yaitu kategori tinggi dengan frekuensi 31, kategori sedang dengan frekuensi 4, dan ketegori rendah dengan frekuensi 0. Hasil data frekuensi skor hipotetik motivasi menyelesaikan skripsi pada mahasiswa tidak bekerja terbagi dalam tiga kategori, yaitu kategori tinggi dengan frekuensi 28, bergerak dari $X<119$ dengan frekuensi 0 .

Hasil kategorisasi dapat disimpulkan bahwa distribusi frekuensi skor hipotetik motivasi menyelesaikan skripsi terlihat bahwa skor hipotetik motivasi menyelesaikan skripsi pada mahasiswa yang bekerja dan mahasiswa yang tidak bekerja berada pada kategori tinggi, meskipun secara persentase berbeda yakni, pada mahasiswa bekerja sebesar $88,6 \%$ dan pada mahasiswa tidak bekerja $56 \%$.

Hasil analisis uji-t diperoleh nilai $\mathrm{t}=4,085$ dengan $\mathrm{p}=0,000$, karena signifikansi uji $\mathrm{t}=0,000<\mathrm{p} 0,01$ artinya sangat signifikan. Dapat disimpulkan bahwa ada perbedaan motivasi menyelesaikan skripsi antara mahasiswa yang bekerja dengan mahasiswa yang tidak bekerja pada mahasiswa jurusan Teknik Informatika UAD, maka hipotesis dalam penelitian ini diterima

Hasil penelitian tersebut sangat mendukung hipotesis yang telah penulis buat yaitu mahasiswa yang bekerja mempunyai motivasi menyelesaikan skripsi lebih tinggi sedangkan mahasiswa yang tidak bekerja memiliki motivasi menyelesaikan skripsi lebih rendah.

Menurut Putri (2006) seorang mahasiswa yang bekerja memiliki waktu yang lebih terbatas dalam menyelesaikan skripsi dibandingkan dengan mahasiswa yang tidak bekerja. Oleh karena itu manajemen diri atau manajemen waktu yang baik perlu dilakukan bagi mahasiswa yang bekerja agar target dalam menyelesaikan skripsi dapat tercapai. Seorang mahasiswa bekerja yang memiliki waktu yang lebih terbatas 
dalam menyelesaikan skripsi biasanya akan lebih temotivasi dan semangat untuk memanfaatkan waktu yang terbatas itu dengan sebaik-baiknya. Berbeda dengan mahasiswa yang tidak bekerja yang memiliki waktu luang lebih banyak daripada mahasiswa tidak bekerja, secara psikologis biasanya orang yang memiliki waktu luang lebih banyak akan cenderung lebih santai dalam mengerjakan sesuatu dan lebih suka menunda-nunda dalam mengerjakan sesuatu (Handoko, 1992).

Menurut Brophy (1990) individu yang memiliki motivasi yang tinggi mempunyai tanggung jawab dalam menyelesaikan tugas, tidak suka membuang-buang waktu serta optimis dalam memandang masa depan. Mahasiswa yang juga berstatus sebagai seorang pekerja biasanya memiliki rasa tanggung jawab yang besar, karena terkondisi dalam tuntutan pekerjanya yang menuntut ia bekerja secara profesional. Rasa tanggung jawab inilah yang kemudian memunculkan motivasi yang tinggi untuk segera menyelesaikan setiap tugas yang dibebankan kepadanya, termasuk beban menyelesaikan skripsinya. Hal inilah yang kemudian menyebabkan mengapa mahasiswa yang bekerja lebih tinggi motivasi menyelesaikan skripsinya, dibandingkan dengan mahasiswa yang tidak sambil bekerja.

\section{Simpulan}

Hasil penelitian yang dilakukan pada mahasiswa yang bekerja dan mahasiswa yang tidak bekerja pada mahasiswa jurusan Teknik Informatika UAD menunjukkan bahwa terdapat perbedaan motivasi menyelesaikan skripsi antara mahasiswa yang bekerja dengan mahasiswa yang tidak bekerja. Mahasiswa yang bekerja mempunyai motivasi menyelesaikan skripsi lebih tinggi sedangkan mahasiswa yang tidak bekerja memiliki motivasi menyelesaikan skripsi lebih rendah dengan demikian hipotesis yang diajukan peneliti diterima.

\section{Daftar Pustaka}

Azwar, S. (2000). Reliabilitas Dan Validitas. Yogyakarta: Pustaka Pelajar.

Bass. (1961). Leadership Psychology and Organi ational Behavior. New York: Harper and Random.

Blum, F. H. (1974). Toward a Democratic Work Process. New York : Greenwood Press.

Brophy, J. E. (1990). Educational Psychology. New York: Longman. 
Chaplin, C. P. (2001). Kamus Lengkap Psikologi. Jakarta: P.T. Raja Grafindo.

Handoko. (1992). Motivasi: Daya Penggerak Tingkah Laku. Kanisius Yogyakarta.

Hadi, S. (2001). Metodologi Panelitian Jilid 1. Yogyakarta: Andi Offset.

Jacinta, R. F. (2002). Wanita Bekerja. WEB: Kompas Cyber Media

Krench, D. (1962). Individual in Society. New York: McGraw-Hill Book Company.

Putri, S. D. (2006). Cari Duit Ala Mahasiswa. Yogyakarta: Galang Press.

Suryabrata, S. (1995). Psikologi Pendididkan. Jakarta: Rajawali Press.

Sya'ban, H. (2006). Menyusun Skripsi Hanyalah Formalitas?. 